レーザー手術特集

\title{
下気道結核後に生じた瘢痕性気管狭窄例
}

——喉頭気管狭窄に対するレーザー手術の臨床的意義—

*斉藤 寿, 田淵光り子

昇卓夫，大山勝

\section{Clinical Advantage of Laser Surgery on Laryngotracheal Stenosis -With Special Attention to Nd-YAG Laser Irradiation Applied to a Case with Tuberculosis -}

\author{
Hisashi Saitoh, M.D., Eriko Tabuchi, M.D., \\ Takuo Nobori, M.D. and Masaru Ohyama, M.D. \\ Department of Otolaryngology, Kagoshima University, School of Medicine, Kagoshima
}

\begin{abstract}
The incidence of laryngotracheal stenosis secondary to traffic accident, labor disaster, malignant neck tumor and extended indication of tracheostomy has been increasing. Because of post-operative granulation and scar formation, it is well known that surgical management of the stenosis of the larynx and cervical trachea is usually difficult and a long therapeutic term is necessary. During the past 4 years, the authors treated 88 patients with both upper respiratory tract and oral cavity lesions using $\mathrm{CO}_{2}$ and Nd-YAG laser irradiation. Among those subjects, six cases had airway stenosis caused by granulation and cicatrice secondary to inflammatory and traumatic lesions. Especially, a rare case with tuberculous tracheal stenosis treated successfully by Nd-YAG laser irradiation using flexible fiberscope was reported and discussed. Laser vaporization would be useful to apply for the respiratory stenosis with less bleeding and scarring.
\end{abstract}

Key words : 気道狭窄, $\mathrm{CO}_{2}$ レーザー, Nd-YAG レーザー, フレキシブルファイバースコープ，管腔藏器

\section{1.はじめに}

1970 年代より $\mathrm{CO}_{2}$, Argon, Ruby レーザー が次々に開発され, 消化器外科, 脳外科, 眼科, 泌尿器科などの各分野で臨床的に応用されてい る。耳鼻咽喉科領域に和いても口腔, 咽頭, 喉 頭の疾患に幅広く用いられている。とくに可撓 性マニュピレーターを備えた Nd-YAG レーザ 一が出現して, その応用範囲は飛躍的に広がっ ている。

一方, 結核性疾患は抗結核剂, 集団検診など *鹿児島大学医学部耳鼻咽喉科
の予防医学の普及などに伴い, 戦後急激な減少 をみたが，その後徐々に増加する傾向がみられ ている。耳鼻咽喉科領域に和いて子最近喉頭そ の他の結核症例の報告が散見されている。

今回われわれは，下気道結核後に生じた高度 の瘢痕性気管狭窄例を Nd-YAG レーザーにて 治療する機会が得られたので, その臨床的経過 の概要を述べるとともに過去 2 年間にレーザー 外科処置を行った気道狭窄例についても供覧 し，これらを中心に気道狭窄とレーザー外科の 問題について，若干の考察を加えて報告する。 


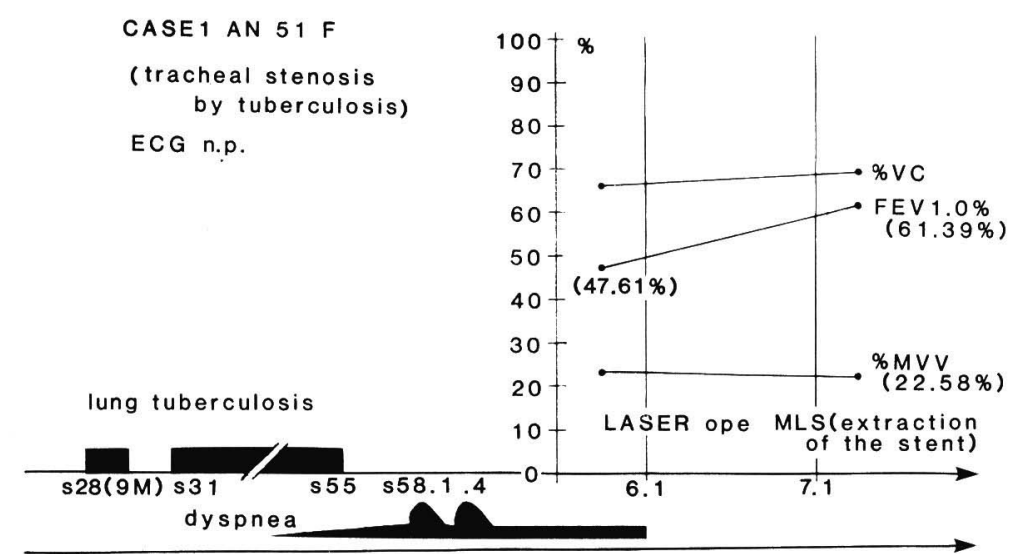

図 1

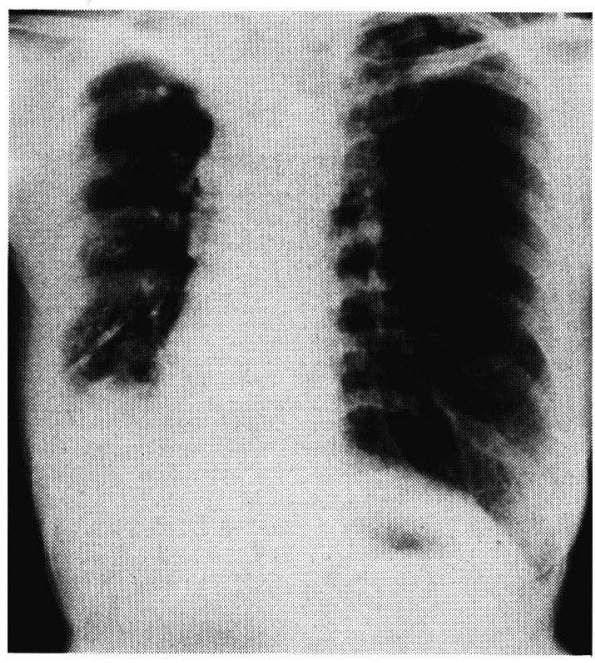

図 2

\section{2. 症例}

症例 1 は51歳の女性で, 呼吸困難を主訴とし て来院した。図 1 はその経過表である。現病歴 では昭和 28 年 8 月より 9 力月間肺結核にて SM, PAS, INH の三者併用療法を行っている。退 院後も抗結核剤の内服を指示されたが，患者は 完治したものと思い完全には服用しなかった。 昭和31年11月再発し, 以後昭和55年まで療養生 活を送っている。昭和 57 年 12 月と翌年 4 月感冒 罹患後高度の呼吸因難が出現し, 結核治療を行 った病院に緊急入院した。その際, 気管狭窄が 疑われて当科に紹介された。

受診時身長 $155 \mathrm{~cm}$, 体重 $38 \mathrm{~kg}$ とるい瘦が著 明で，中程度の呼吸困難が認められた。間接喉 頭鏡で声門下に小孔をもった洀痕狭窄を認めた

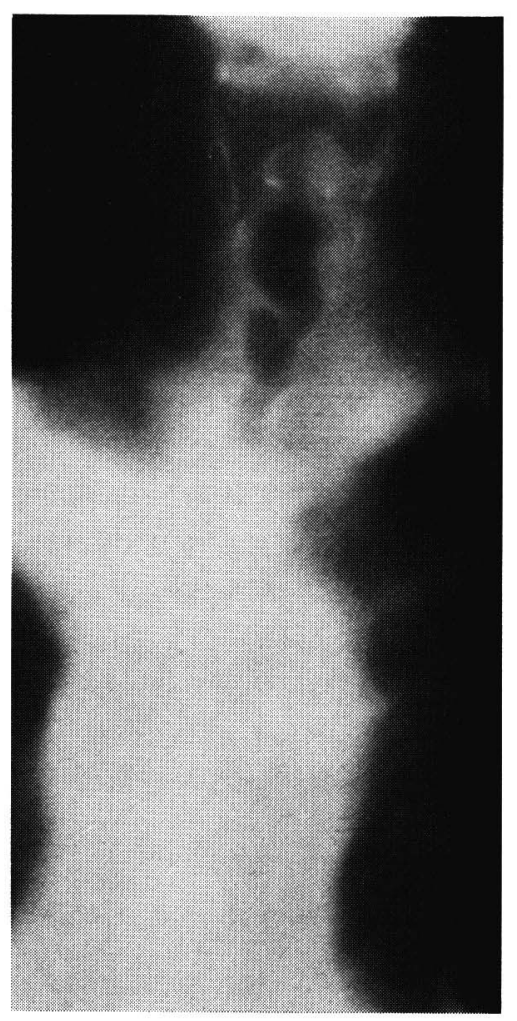

図 3

が，その全貌を観察するまでには至らなかっ た。胸部 X線写真にて両側肺尖部を中心とした 両肺の瘢痕収縮, 肺縦隔の右方移動, 肺血管, 気管の挙上などが認められた（図 2 )。喉頭多 軌動断層写真で第 1 気管輪部に高度の狭窄（図 3）と気管分岐上に約 $3 \mathrm{~cm}$ 長にわたる 軽度の 狭窄が存在した。血管撮影で両側肺動脈が上方 


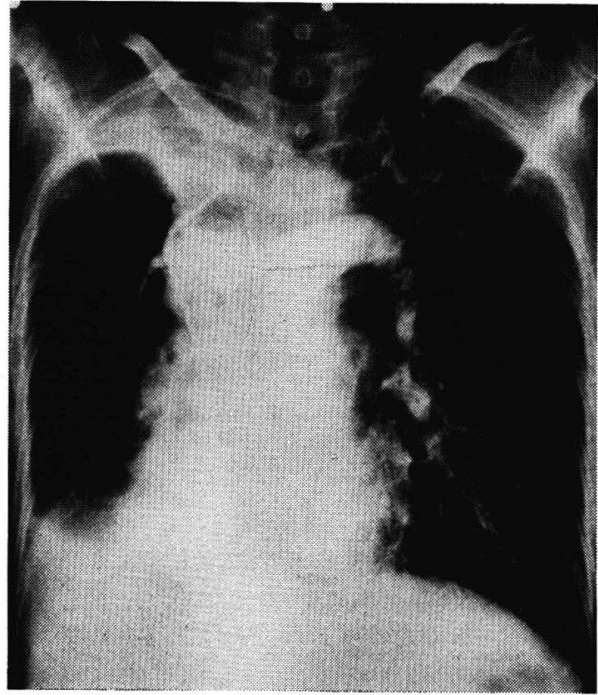

図 4

に偏位し，右上肺野には動脈陰影がほとんど認 められず，鎖骨下動脈も右方に偏位していた (図 4 )。99mTc-MAA 肺シンチグラフィーでも 右肺の肺尖部, 下肺野, 左肺の肺門から肺尖に わたる欠損像が 認められた（図 5 )。喉頭 フレ キシブルファイバースコープで声門下に 3 個の 小孔をもった高度の膜状狭窄が認められ，これ が呼吸困難の主因と考光られた。昭和 56 年 6 月 1 日レーザーによる疲痕除去術を行った。まず 局麻下に第 II， II 気管輪に気管切開を行った。 これにより患者の呼吸困難は著明に改善した。 図 6 は気切部よりフレキシブルファイバースコ ープにて上方の膜状狭窄部分を観察したもので ある。この洀痕部分を $\mathrm{Nd}-\mathrm{Y}$ AG レーザーを用いて声門が 十分観察されるまで焼灼した (図 7 )。

一方, 下方の狭窄部は比較 的軽度で呼吸困難の原因とな るほどではないと判断したの で，そのまま放置した。焼灼 後同部にステントを挿入し固 定した（図 8 )。1 1 月後断 層, CT 写真にてステントと 気管壁間に肉芽発生のないこ とを確認した上で（図 9), microlaryngoscopy （以下,

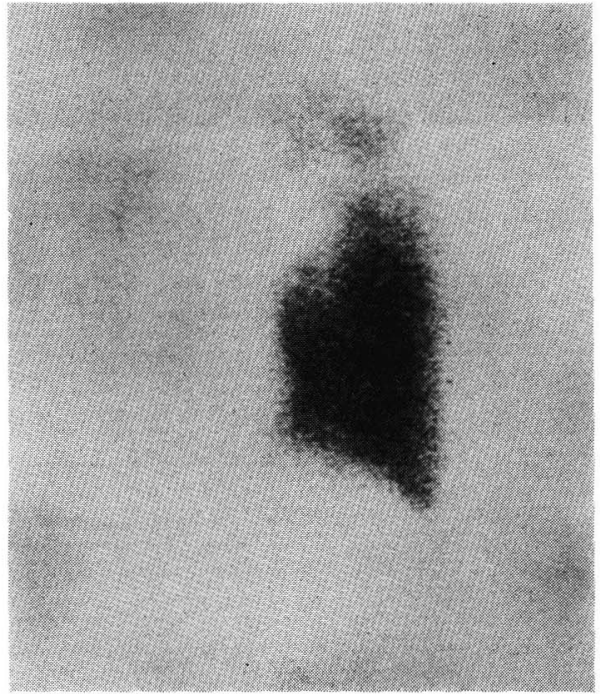

図 5

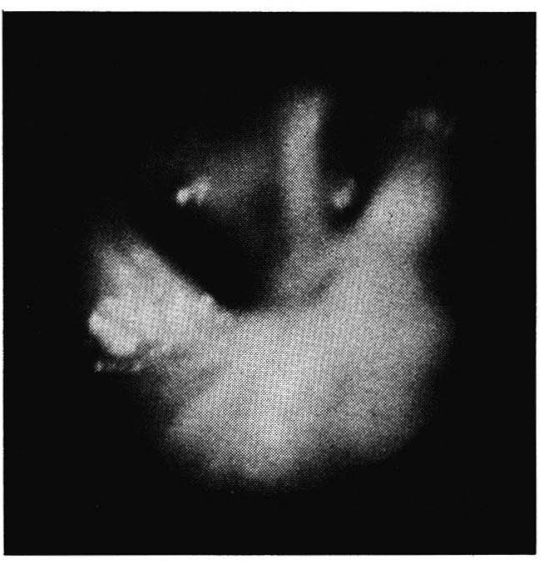

図 6

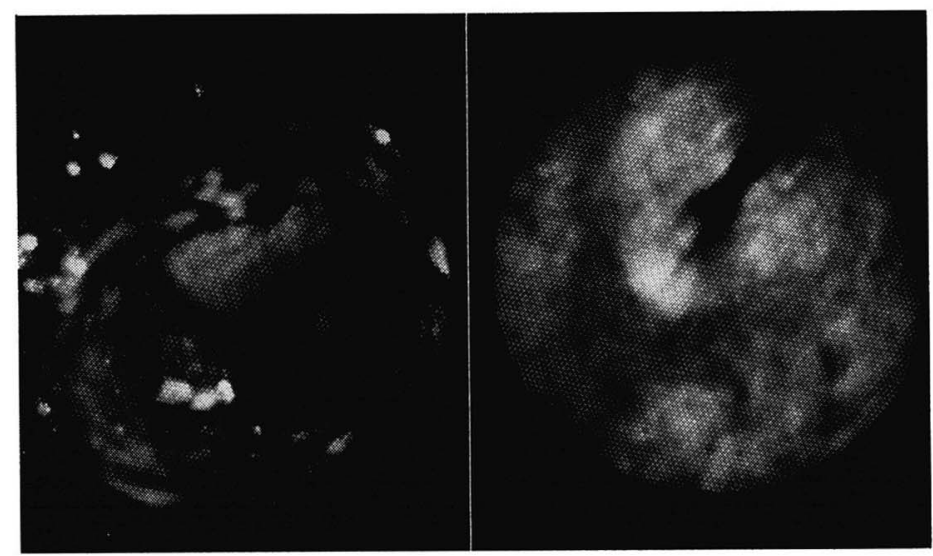

図 7 


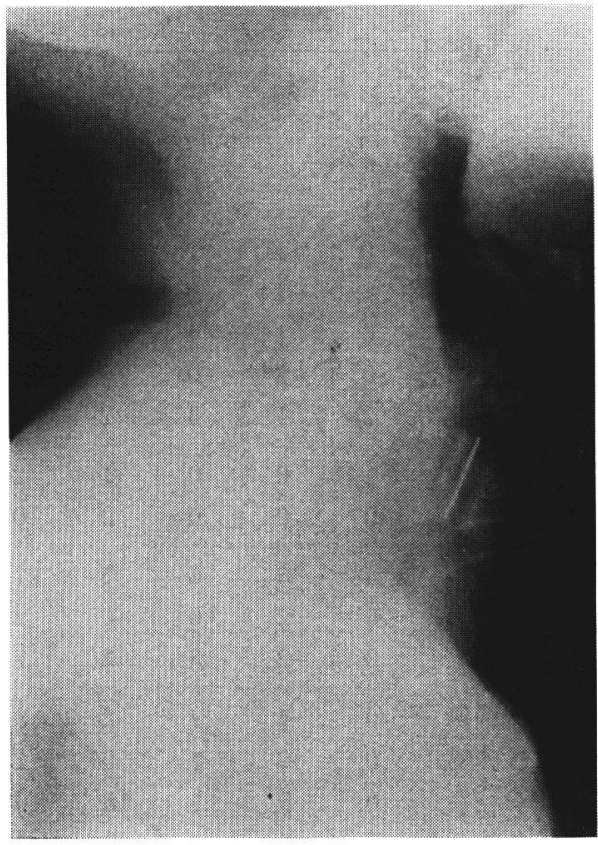

図 8

MLS と略す）下にステントを抜去した。肺機 能検査では 1 秒率が $47.61 \%$ から $61.39 \%$ と改善 している(図 1)。現在外来にて follow-up 中で あるが経過良好で，焼灲創も上皮下されて呼吸 困難もなく，社会復帰し，日常生活を送ってい

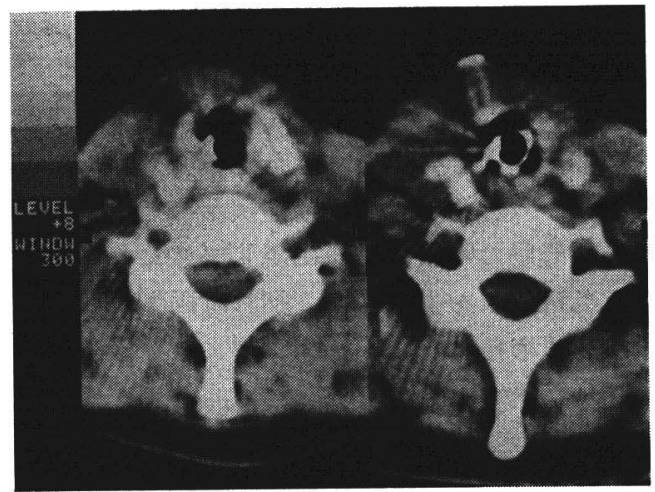

図 9

る。

その他レーザー手術を行った気道狭窄 4 症例 について報告する（表 1 )。

症例 2 は36歳の女性で主訴は嗄声である。昭 和57年 3 月全麻下に胃潰瘍の手術を行ってから 嗄声が出現し, 徐々に増悪してきた。 5 月当科 外来を受診した。両側声帯後連合付近に直径約 $5 \mathrm{~mm}$ の有茥性の肉芽を認めたため, MLS 下に 鉗除した。病理学的には潰瘍を伴った肉芽であ った。その後右声帯肉芽のみ再発を認めたため 9 月に MLS 下に銈除しさらに周囲を含めて 5 \%硝酸銀で焼灼した。その後も再発を認めたた

表 1

\begin{tabular}{|c|c|c|c|c|c|}
\hline 症例 & $\begin{array}{l}\text { 年齢 } \\
\text { 性 }\end{array}$ & $\begin{array}{ll}\text { 原 } & \text { 因 } \\
\text { 診 } & \text { 断 }\end{array}$ & 法 & レーザー手術時の局所所見 & 帰 \\
\hline 2. & $\begin{array}{l}36 \text { 歳 } \\
\text { 女 }\end{array}$ & 捰 管 & $\begin{array}{l}\text { 鉗除 } \\
\text { 硝酸銀焼灼 } \\
\mathrm{CO}_{2} \text { レーザー手術 (2回) }\end{array}$ & & 経過観察中 \\
\hline 3. & $\begin{array}{l}36 \text { 歳 } \\
\text { 男 }\end{array}$ & $\begin{array}{l}\text { 交 通 事 故 } \\
\text { 両側反回神経麻猈 }\end{array}$ & $\begin{array}{l}\text { 気管切開 } \\
\text { 喉頭前方開大術 ( } 2 \text { 回) } \\
\mathrm{CO}_{2} \text { レーザー手術 ( } 2 \text { 回) }\end{array}$ & & 経 過 良好 \\
\hline 4. & $\begin{array}{l}50 \text { 歳 } \\
\text { 女 }\end{array}$ & $\begin{array}{l}\text { 甲 状 腺 癌 } \\
\text { 両側反回神経麻㾝 }\end{array}$ & $\begin{array}{c}\text { 気管切開 } \\
\text { 喉頭前方開大術 } \\
\mathrm{CO}_{2} \text { レーザー手術 } \\
\text { (左声带切除) }\end{array}$ & & 経 過良好 \\
\hline 5. & $\begin{array}{l}\text { 30歳 } \\
\text { 男 }\end{array}$ & $\begin{array}{c}\text { 反復性多発性 } \\
\text { 軟骨膜炎 } \\
\text { 声門下狭窄 }\end{array}$ & $\begin{array}{l}\text { 気管切開 } \\
\text { 喉頭形成術 (2 回) } \\
\mathrm{CO}_{2} \text { レーザー手術 (3 回) }\end{array}$ & , & 永久気管孔形成 \\
\hline
\end{tabular}


め 2 回の $\mathrm{CO}_{2}$ レーザー手術を行い現在経過観 察中である。

症例 3 は36歳の男性で昭和 48 年 4 月交通事故 で頭部，喉頭の外傷を受けた。某脸外科にて約 3 力月の入院治療と 1 年の通院治療を行ってい たが，軽度の呼吸困難が出現してきたため昭和 52 年当科外来を受診した。初診時両側反回神経 麻疾が認められた。昭和 54 年頃より呼吸困難が 増悪し不眠も出現してさたため, 外来にてステ ロイドのネブライザーなどで治療を行った。し かし昭和56年 3 月呼吸困難がさらに強くなり, 気管切開後声門前方開大術を行ったが，呼吸困 難は改善しなかった。そこで軟骨移植による喉 頭形成術を行った。これにより声門の開大は認 めたものの前連合声門下腔に限局性の肉芽形成 を認めるようになった。6 月以降 3 回の MLS レーザー手術，ステロイドのネブライザー治療 を行い肉芽の消失をみた。昭和 57 年 2 月カニュ ーレを抜去したが労作時にも呼吸困難は出現し ていない。

症例 4 は50歳の女性で, 主訴は呼吸困難であ る。昭和 55 年 12 月甲状腺癌の診断で他科飞て全 麻下に気管切開, 甲状腺部分切除, 右頸部廓清 術を受けている。直後より嗄声と軽度の呼吸困 難が出現した。昭和56年 2 月感冒罹患後に高度 の呼吸困難が出現した。昭和57年 6 月両側反回 神経麻痺の診断の下に気管切開, 声門前方開大 術を行った。カニューレ抜去後も若干の呼吸困 難が残り，感冒罹患時に増悪する状態であった ので, 同年 8 月 $\mathrm{CO}_{2}$ レーザーによる左声帯切 除，ステロイド漸減療法を行った。気管切開は 必要とせず，退院後も経過良好である。

症例 5 は30歳の男性で, 昭和 45 年リューマチ 熱に罹患している。その後両足関節，両肘関節 の疼痛が持続し，ステロイド剂の内服治療を行 っている。昭和53年頃より鼻閉, 呼吸困難が出 現し, 徐々に高度となった。当科にて鼻中隔軟 骨より試切を行い, 多発性反復性軟骨膜炎の診 断を得た。昭和54年 5 月 MLS 検査にて声門下 腔のロート状狭窄を認めたため，気管切開を行 った。昭和 55 年 9 月上顎洞前壁移植片を用い て，2段階にわたって喉頭形成術を行った。手 術直後より声門下腔に再び肉芽形成をみたた め, 昭和56年 9 月 $\mathrm{CO}_{2}$ レーザー手術を試みた
表 2

\begin{tabular}{|c|c|c|c|c|c|}
\hline 疾患 $\begin{array}{c}\text { 年度 } \\
\text { (昭和) }\end{array}$ & 55 & 56 & 57 & 58 & 計 \\
\hline \multicolumn{6}{|l|}{ 口腔悪性腫瘍 } \\
\hline 頬粘膜 & 1 & 1 & 2 & 0 & 4 \\
\hline 舌 & 0 & 1 & 1 & 3 & 5 \\
\hline 扁桃 & 1 & 1 & 0 & 0 & 2 \\
\hline 口腔底 & 0 & 1 & 4 & 0 & 5 \\
\hline 口蓋 & 0 & 2 & 0 & 0 & 2 \\
\hline 良性腫瘍 & 2 & 1 & 3 & 2 & 8 \\
\hline 咽頭悪性腫瘍 & 1 & 0 & 0 & 1 & 2 \\
\hline 良性腫瘍 & 0 & 0 & 0 & 0 & 0 \\
\hline 喉頭悪性腫瘍 & 4 & 6 & 6 & 5 & 21 \\
\hline 良性腫瘍 & 0 & 2 & 0 & 0 & 2 \\
\hline その他 & 0 & 2 & 3 & 2 & 7 \\
\hline 上顎悪性腫瘍 & 0 & 4 & 2 & 2 & 8 \\
\hline 良性腫瘍 & 0 & 0 & 1 & 0 & 1 \\
\hline 副鼻腔炎 & 0 & 0 & 1 & 15 & 16 \\
\hline その他 & 0 & 2 & 1 & 0 & 3 \\
\hline そ の 他 & 0 & 0 & 0 & 2 & 2 \\
\hline 計 & 9 & 23 & 24 & 32 & 88 \\
\hline
\end{tabular}

が, 狭窄範囲が長く全肉芽の焼灼は不可能であ った。同年 5 月声門直下より気切孔までの肉芽 を鉗除し $\mathrm{CO}_{2}$ レーザーで焼灼した後, 直径 6 $\mathrm{mm}$ のシリコンチューブを插入し，ステロイド 剂の内服を併用した。シリコンチューブ抜去直 後から粘膜が全周性に浮腫状に腫脹していたた め, 間隙はほとんど認めない状態であった。こ のため, 永久気管孔形成のやむなきに至った。

\section{3. 考按}

われわれの教室では昭和 55 年にペンタックス $\mathrm{CO}_{2}$ サージカルレーザ (model SLC-1), 昭和 58 年にペンタックス Nd-YAG レーザー (model SLY-1) が導入され, さまざまな疾患に応 用している。表 2 は昭和 58 年 12 月までのレーザ 一手術症例である。喉頭疾患が 30 例と最も多 く, 次いで上顎, 口腔, 咽頭の順で, これらの総 計は88症例である。悪性腫瘍はもち論ロイコプ ラキー, さらには上顎のネクロトミー症例など が含まれ，症例によっては腫瘍の再発ごとにレ 一ザー手術を行い，良好な結果を得ている。ま 
たその他鼻孔閉鎖や鼻出血，扁桃炎に至るまで さまざまな症例がレーザー手術の対象となって いる。今回はこれらの中で気管狭窄，とくに結 核後の気管瘕痕狭窄例を中心にレーザー手術の 効用について報告した。

咽喉頭結核は昭和 23 年以後 急激な減少を示 し，昭和30年代からはほとんどこれを診る機会 がなくなった。しかし，最近は再び結核症例が 少しずつ目に止るようになり，その病像や罹患 年齢などの点で大きく変化していると言われ

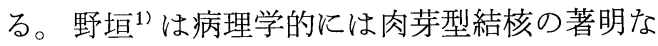
増加を大きな変化として特徴づけている。とこ ろで上気道結核の汪とんど全ては肺結核からの 二次感染で, その診断には既応歴, 胸部 X線写 真, 組織診断が必要である ${ }^{2)}$ 。第 1 症例は手術 時摘出した組織診断にて軽度の炎症を伴った線 維組織, いわゆる疲痕治瘉の状態で, 喀痰検査 で結核菌陰性であった。しかしながら，胸部X 線写真では両肺の荒無状態が認められた。

ところで気道面積が約 $1 / 3$ に狭小化すると高 度の呼吸困難が出現することが知られている が3)，本症例の場合，かなり長期間にわたって 慢性的に気道狭窄が進行したために, 病像に比 して臨床症状が予想以上に軽かったものと考光 られる。戦前肺結核の末期的病像であった上気 道結核が，化学療法の発達により結核菌そのも のに対する制圧は可能になり，高度の瘢痕を残 して治癒した化学療法剤開発後の特異的な症例 と言える。

一方, 交通事故, 労働災害の増加, 気管切開 適応拡大による套管抜去困難症の増加, 頸部悪 性腫瘍などによる手術症例の増加などさまざま な原因により，喉頭・気管狭窄例は著しく増加 している。しかしこれら症例に対する治療は術 後の肉芽形成や再狭窄のためきわめて難しく, すでに多くの人々によりさまざまな治療法が検 討されている。それらの多くは観血的な気道形 成が主軸であるが，治療期間が長期にわたるな どの問題点が残されていた。その点，レーザー 手術は局所反応が軽微で過剩肉芽, 瘢痕形成が 少ないなどの特徵が知られているので，本領 域への臨床的応用が期待される。事実，最近気 道狭窄に対するレーザー外科による良好な治療 成績が報告されつつある。当教室では黒野ら ${ }^{5) 6)}$
表 3

1. レーザーの利点

1）出血が少なく手術時間の短縮ができる

2) 過剰肉芽，痽痕形成が少ない

3）術創の治癒が早い

4）術後の疼痛が少ない

2. $\mathrm{CO}_{2}$ レーザーと YAG レーザーの比較

\begin{tabular}{|c|c|c|}
\hline & $\mathrm{CO}_{2}$ レーザー & YAG レーザー \\
\hline $\begin{array}{l}\text { エネルギー } \\
\text { の吸収 }\end{array}$ & $\begin{array}{l}\text { 表層に高エネル } \\
\text { ギーが集中 }\end{array}$ & 深部に透過 \\
\hline $\begin{array}{l}\text { 組織表面の } \\
\text { 反射 }\end{array}$ & 小 & 大 \\
\hline 止 血 能 & 小 & 大 \\
\hline 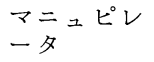 & 硬 性 & 柔 \\
\hline 創 傷治瘉 & 早 い & 遅 \\
\hline
\end{tabular}

が口腔，喉頭腫瘍を中心に 31 症例について $\mathrm{CO}_{2}$ レーザー手術を行い，悪性腫瘍でも $68 \%$ とかな りの有効率があったことを報告した。また三橋 ら 7) 喉頭腫瘍を中心に 184 例レーザー手術を 行い良好な成績を報告している。その中で $\mathrm{CO}_{2}$ レーザーによる顕微鏡下手術はマニュピレータ 一が硬性のため声帯レベルまでしか到達できな いことから独自の laser tracheoscope を開発 し, 胸部気管狭窄例に臨床的に有用性が高く, レーザー手術の絶対的適応であると結論づけて いる。症例 1 は第 1 気管輪の高さに膜状狭窄が 存在し, $\mathrm{CO}_{2}$ レーザーでは到達不可能と思わ れた。そこで可撓性のある Nd-YAG レーザー を用い気管切開空よりフレキシブルファイバー スコープ下に焼灼した。術後肉芽, 瘢痕形成は みられず，わずか 1 カ月でステントを抜去する ことが可能であった。表 3 はレーザー手術の利 点について $\mathrm{CO}_{2}$ レーザーと Nd-YAG レーザ 一のそれぞれの特徵を比較列挙したものであ る。Nd-YAG レーザーはマニュピレーターが 柔性でありフレキシブルファイバー下に手術が 可能であるので, 気道, 消化器はもちろん泌尿 器, 産婦人科領域の管腔藏器に最も適している と考光られる。症例 $2,3,4$ は声帯もしくは声 帯直下の病変であり $\mathrm{CO}_{2}$ レーザーにて治療を 行った。症例 2 と 3 は插管後と声門前方開大術 後の肉芽腫症例であり, 症例 4 は声門前方開大 術後の声帯切除症例であった。3 例とも限局し た病変であり, レーザーで焼灼するのみでステ 
ソトなどの補助的手段は必要としなかった。症 例は反復性多発性軟骨膜炎の症例で全身性疾患 の一部分症として気管軟骨自身の病変をきたし たもので, 本来レーザー治療の適応を越えたも のである。

最後に, レーザー外科の新しい応用領域とし て, 当教室では現在フレキシブルファイバース コープ下に Nd-YAG レーザーを用いた慢性上 顎洞炎手術への使用を試みている ${ }^{899)}$ 。これは 閉塞した自然孔の開大と病的洞粘膜の焼灼を行 らなどして，洞の形態と機能保持を目指した新 しい試みである。本術式は局所での侵襲が少な く高い治癒率を挙げることに成功している。こ のようにレーザー手技は単に悪性腫瘍のみなら ず，狭窄部の開大を必要とするさまざまの疾患 に応用されて, その効果が期待されるものと確 信する。

\section{4. まとめ}

結核後に生じた高度の瘢痕性気管狭窄例を中 心に，当教室でレーザー手術を行った非腫瘍性 気道狭窄について報告した。気道をはじめとす る管腔臓器の狭窄部の開大手術にレーザーとく に Nd-YAG レーザーが有用である。

\section{引用文献}

1) 野垣俊幸：最近に护ける咽喉頭結核の様相, 日気 食会報, $23: 185-190,1972$.

2) 豊田文一・他：咽喉頭狼滄について，耳喉，38： 187-190, 1966.

3 ) 浅井末得: 気管・気管支の成形, 日気食会報, $14: 69-72,1963$.

4) 大久保泰: 顕微鏡下喉頭内レーザー手術に関す る基礎的研究, 耳鼻, $26: 29-43,1980$.

5 ) 黒野祐一・他：頭頸部腫瘍に対するレーザー手 術の検討, 耳鼻臨床, 75:1525-1533, 1982.

6 ）黑野祐一・他：口腔癌に対する新しい併用療法 の試み, 耳鼻, $29: 353-359,1983$.

7) 三橋重信・他：耳鼻咽喉科に叔けるレーザー手 術の可能性々限界, 耳鼻臨床, $74: 2767-2782,1981$.

8 ）大山勝 : 上気道粘膜の病態生化学一診断と治療 への結びっき—, 斯文堂, 鹿児島市, pp. 110-115, 1984.

9 ) Ohyama, M. et al. : Indication and procedures of physiological antrostomy for the sinus lesions. Rhinology, $23: 1985$, in press.

10）医学のあゆみ，第 5 土矅特集、レーザー医学, $124: 1983$.

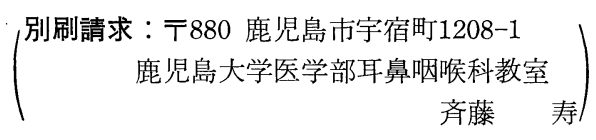

（投稿受付 1984年 6 月 6 日） 